\title{
The Belt and Road Initiative's Impact on China's Outward Foreign Direct Investment
}

\author{
Shaosong Wang ${ }^{1}$ Weihua A. Liu ${ }^{1, *}$ \\ ${ }^{1}$ Business School, Macau University of Science and Technology, Macao, China \\ *Corresponding author. Email: a_s_lewis@hotmail.com
}

\begin{abstract}
The Belt and Road Initiative (BRI) is one of China's important foreign policies to strengthen economic ties with the countries along the Belt and Road. This project applies the Propensity Score Matching technique to prove that the Belt and Road Initiative treaties have significant positive impacts on China's outward Foreign Direct Investment (FDI) in the host countries. Except for the countries along the Belt and Road, even the countries with similar characteristics to those, if they sign the relevant treaties with China, China's outward Foreign Direct Investment to these economies may increase.
\end{abstract}

Keywords: the Belt and Road Initiative, BRI, BRC, FDI, China

\section{INTRODUCTION}

The Silk Road Economic Belt and the Twenty-First Century Maritime Silk Road Initiative (hereinafter referred to as the Belt and Road Initiative, or BRI) has been an important concept and platform for international economic cooperation. On September 7th, 2013, during his visit to Kazakhstan Chinese president Xi Jinping proposed to build the Silk Road Economic Belt. And during his visit to Indonesia on October 3rd in the same year, Xi raised the initiative to build the Twenty-First Century Maritime Silk Road.

Afterwards the Chinese government integrate the two concepts and endeavored to transfer them into reality. In March 2015, the National Development and Reform Commission, the Ministry of Foreign Affairs, and the Ministry of Commerce of the People's Republic of China issued the "Vision and Actions on Jointly Building Silk Road Economic Belt and 21st Century Maritime Silk Road"[1]. This document designed the blueprint for building the Silk Road Economic Belt and the 21st Century Maritime Silk Road. The initiative targets to revive the Silk Roads connecting China and many western Countries in Asia and Europe since Han Dynasty, including the countries in Central Asia, Russia, the Persian Gulf, West Asia, the Mediterranean Sea and Europe. While the "Maritime Silk Road" connects China and Southeast Asia, the Middle East, East and North Africa, and the countries surrounding the Mediterranean. The first Belt and Road Forum for International Cooperation was held in 2017 in Beijing, China's capital. The initiative attracts many countries to participate in the joint building of the Best and Road.

*Project: Sponsored by Macau University of Science and Technology. Project code: FRG-19-037-MSB.
Now the initiative covers seven-tenth of global population and more than six-tenth of the total Gross Domestic Product (GDP) of the world [2]. By the end of March 2019, 173 cooperation agreements about the BRI had been signed by China and 125 countries and 29 international organizations [3].

In addition, the BRI receives great support from international organizations. On November 17th, 2016, in a resolution by consensus of 193 members of the United Nations, the BRI was welcome and a secure environment for the initiative was called on. On March 17th, 2017, the Resolution 2344 unanimously adopted by the UN Security Council also called on to enhance regional economic cooperation through BRI.

The main goals of BRI includes "promoting policy coordination, facilitating connectivity, unimpeded trade, financial integration and people-to-people bonds". The "Vison and Actions" document of BRI stated that "we should speed up investment facilitation, eliminate investment barriers, and push forward negotiations on bilateral investment protection agreements and double taxation avoidance agreements to protect the lawful rights and interests of investors." [1]

Many economic and trade cooperation zones in China and other countries along the Belt and Road (later referred as BRC) were erected, which are important platform for mutual investment, such as the China-Belarus Industrial Park, the Thai-Chinese Rayong Industrial Zone, the Egypt Suez Economic and Trade Cooperation Zone, and so on [4].

According to the statistics of a Chinese official document, the total Foreign Direct Investment (FDI) from China to the countries along the Belt and Road 
from the Year 2013 to the Year 2018 were more than ninety billion U.S. dollars. In 2018, China's outward non-financial direct investment in the Belt and Road countries were 15.6 billion U.S. dollars, accounting for $13 \%$ of China's total value in that year [3].

This paper will measure BRI's impact on China's outward FDI, and test whether the FDI will increase if BRI treaties are signed by China and the host countries currently out of the Belt and Road but with similar features with current BRCs.

The next part is the literature review, the third part is the research design, and the results are discussed in the fourth part. Finally, a conclusion is conducted.

\section{LITERATURE REVIEW}

After the Global Financial Crisis in 2008, the economic growth of China was slowed down, the government and many economists attribute the sluggishness to China's imbalanced economic structure and overcapacity. Huang (2016) argues that the aim of the BRI is to rearrange China's external economic relations to sustain its robust economic progress [5]. Besides, Wang (2016) regards the BRI as an important international public good provided by China to enhance the economic exchange and collaboration among the countries in Asia, Oceania, Europe and Africa. As an open and inclusive arrangement for international cooperation [6]. BRI can augment China's outward investment and diversify its energy sources and could help the emerging economies along the Belt and Road in modernization and poverty reduction [7].

International economic cooperation includes international trade and international investment. It is well recognized that the BRI reduce trade costs [8] and promotes China's international trade with countries along the Belt and Road [9]. Fu et al. (2018) prove that China export more to the countries with "smaller geographic, factor endowment, and cultural distance and greater institutional distance from China" along the Belt and Road [10].

In general, most literatures about BRI admitted the positive impact of the initiative on China's outward FDI into the BRCs. Du and Zhang (2018) stated that the outward direct investment was raised considerably along the Belt and Road, especially in countries in Central and West Asia, Western Europe and Russia [11].

However, the specific effect of the initiative has not been recognized unanimously when other factors are considered. Kang et al. (2018)'s study indicates that from 2010 to 2015, the outward FDI from China into the countries from the countries on the Belt and Road was around four tenths higher than in the countries out of the Belt and Road. After 2013, China's FDI to BRI countries grows by about $46 \%$. Nevertheless, with keeping other factors constant, the BRI could not be proved to have positive effect on China's FDI in the BRCs [12]. Yu et al. (2019) also admits the positive effect of the BRI on China's outward FDI; yet they reveal that the initiative fosters more investment into developing countries along the Belt and Road [13]. Meanwhile Liu et al. (2017) discloses that the causes of China's outward FDI along the Belt and Road are different from the economies outside of the Belt and Road, and specify the FDI out of China to the Belt and Road countries is more "sensitive to exchange rate, market potential, openness and infrastructure of the host countries" [14]. And Huang (2019) suggests that Chinese corporations choosing host investment countries consider their environment and resource potential [5].

\section{RESEARCH DESIGN}

Two levels of data are usually used in the study of international investment. Du and Zhang (2017), Yu et al. (2019) use the data from China's outward investment enterprises [11], [13]. While, most of the studies include Liu et al. (2017), Duan et al. (2018), Kang et al. (2018), Huang (2019) utilize the data from the host countries. This paper follows the latter approach to use the data on the country level [14], [15], [12], [5].

The dependent variables of former studies, e.g. Liu et al. (2017), Kang et al. (2018), Yu et al. (2019), are usually from the Ministry of Commerce from China [14], [12], [13]. Only Du and Zhang (2018) study the data from China Global Investment Tracker [11]. This paper will use the Data from the EMED (Emerging Market Economic Data) database, which has not been widely used on this topic. The dependent variable of this paper is the logarithm of the outward direct investment position of China in the host country ODIP_C_LN.

The data of most studies on BRI is usually before the Year 2015. For instance, Du and Zhang (2018)'s data ranges from 2005 to 2015 [11], Kang et al. (2018) covers the data from 2010 to 2015 [12], Liu et al. (2017)'s data are from 2003 to 2015 [14], Yu et al. (2019) studies the data from 2000 to 2015 [13]. This paper would update the data to 2018, which covers the range between 2009 to 2018, which might offer new information on the effects BRI on the latter years.

Some researchers such as Duan et al. (2018), Huang (2019), Yu et al. (2019) only study the data of the countries on the Belt and Road [15, 5, 13]. However, the increase of China's outward FDI in BRCs may be not significant comparing with other countries out of the Belt and Road in the same period. Du and Zhang (2018) compares the BRCs and six other countries out of the Belt and Road, such as "Australian, Canada, Japan, Singapore, the United Kingdom and the United 
States" [11]. Furthermore, the study of Liu et al. (2017) includes 44 non-Belt and Road countries for a comparison [14]. Kang et al. (2018)'s research covers 216 countries, including 74 BRCs, and 142 non-Belt and Road countries and applies difference in difference approach to evaluate the impact of BRI on China's outward FDI [12].

The main object of the study on the initiative's effects on China's outward FDI is the BRI. Some scholars such as Du and Zhang (2018), Liu et al. (2017), Duan et al. (2018), Kang et al. (2018), Huang (2019), Yu et al. (2019) use whether a country is on the list of China's roadmap of BRI to dummy the BRI [11, 14, 15, 12, 5, 13]. Some authors, e.g. Du and Zhang (2018), Kang et al. (2018), use the time dummy variable after China proposed the BRI in 2013 to represent the initiative $[11,12]$. As a result, their data after the shock of BRI only includes two years. Besides, whether the bilateral economic relations between the host country and China is not influenced by whether the country is on China's roadmap of the BRI in substance but is affected by the actual implementation of the treaties about BRI between the two countries. In order to capture the substantial effect of BRI, this paper use whether a country has treaties on BRI on China TREATY to dummy BRI. The information is from the official portal of Belt and Road hosted by Chinese government

https://eng.yidaiyilu.gov.cn/info/iList.jsp?cat_id=10061

In order to evaluate the BRI's effects on China's outward investment into the host countries, we control the changes of covariates. According to the theory of Dunning (1977), the multinational enterprises can have three advantages, such as "Ownership, Location, and Internalization" by outward FDI, behind which there are three motivations, "market seeking, efficiency seeking, resource and strategic asset seeking" [16].

Buckley et al. (2007), Zhang and Daly (2011), Kolstad and Wiig (2012) found that the market size is a main determinant of China's outward FDI [17], [18], [19]. Following them, in order to control the market effect, this study controls the logarithm of GDP of the host countries GDP_LN from the Data of the World Bank.

In General, efficiency means low cost. The macro environment also influences the efficiency of multinational enterprises' performance. Kolstad and Wiig (2012) find that China's outward FDI is attracted to countries with poor institutions [19]. Wang et al. (2015) uncover that government effectiveness, regulatory quality, and control of corruption have substantial impacts on Chinese MNE's choice of locations [20]. Following the above researches, this paper also controls the institutional factors based on the Worldwide Governance Indicators (WGI) by the World
Bank. WGI have six dimensions, such as "voice and accountability, political stability and absence of violence/terrorism, government effectiveness, regulatory quality, rule of law, and control of corruption". We first get standardized governance distance $\mathrm{D}$ in each dimension between the host country and China by the following equation, then get the first principal component of the standardized governance distances in six dimensions WGI_D using principal component analysis.

$$
D=\left(V-V_{c}\right) /\left(\sqrt{S^{2} / N}+\sqrt{S_{c}^{2} / N_{c}}\right)
$$

Note: $\mathrm{V}$ and $\mathrm{Vc}$ are the estimated value on governance qualities of the host country and China respectively, $\mathrm{S}$ and $\mathrm{Sc}$ are the standard error of the governance qualities of the host country and China respectively, and $\mathrm{N}$ and $\mathrm{Nc}$ are the number of sources of the data in the host country and China respectively.

It is universally agreed that Chinese initiates outward FDI to seek natural resources, by scholars such as Buckley et al. (2007), Zhang and Daly (2011), Kolstad and Wiig (2012) [17, 18, 19]. Following them we also control the data of the logarithm of total natural resources rents (\% of GDP) of the host country RES GDP LN from the World Bank.

Besides, Buckley et al. (2007) discover that China's outward FDI are associated with cultural and geographic proximity [17]. We also control the cultural factor by including the data from Global Leadership and Organizational Behavior Effectiveness (GLOBE) project in the University of Pennsylvania and the distance data DIST from Recherche et Expertise sur L'Économie Mondiale (CEPII), which is the simple distance of the most populated cities between two countries.

Most studies on the relations culture and economy use the data from Hofstede (2001), which may be a little old-fashioned [21]. Hence, we choose to utilize the data of GLOBE which is newly updated. On the other hand, the sample of Hofstede (2001) only includes the staffs of IBM in 64 countries, and considers six dimensions, "individualism vs. collectivism, power distance, achievement vs. nurturing orientation, uncertainty avoidance, long-term vs. short-term orientation" [21]. Meanwhile the GLOBE's sample are much huger, and covers more dimensions, including "performance orientation, assertiveness, future orientation, humane orientation, institutional collectivism, in-group collectivism, gender egalitarianism, power distance and uncertainty avoidance". Because the nine cultural dimensions are interrelated, we reduce the dimensions into three by the principal component analysis technique. GLOBE_V_1 mainly covers performance orientation, future orientation, in-group collectivism, humane orientation, 
shorter power distance; GLOBE_V_2 mainly gauges gender inegalitarianism and uncertainty avoidance; and GLOBE_V_3 mainly covers assertiveness and week institutional collectivism.

In this project, we utilize Propensity Score Matching (PSM) technique to evaluate the effects of treaties of BRI on China's outward FDI. The mechanism of this method is to compare the dependent variable (ODIP_C_LN) between the treated (TREATY=1) and the control (TREATY=0) observations. The control observations are selected by the nearest neighbor matching method, which finds the four observations with the nearest matching scores calculated with reference to covariates with each treated variable. The weighting matrix is the inverse variance.
We also correct the bias due to the uncertainty of assessing the matching scores and the heteroskedastic errors.

\section{RESULTS AND DISCUSSION}

The graph below shows that the standardized bias of the matched covariates is much less than the unmatched covariates in general, except RES_GDP_LN, which shows that the matching is well performed. We can compare the BRI Treaty's effects on China's FDI outward to the host countries with other countries. (See "Fig. 1")

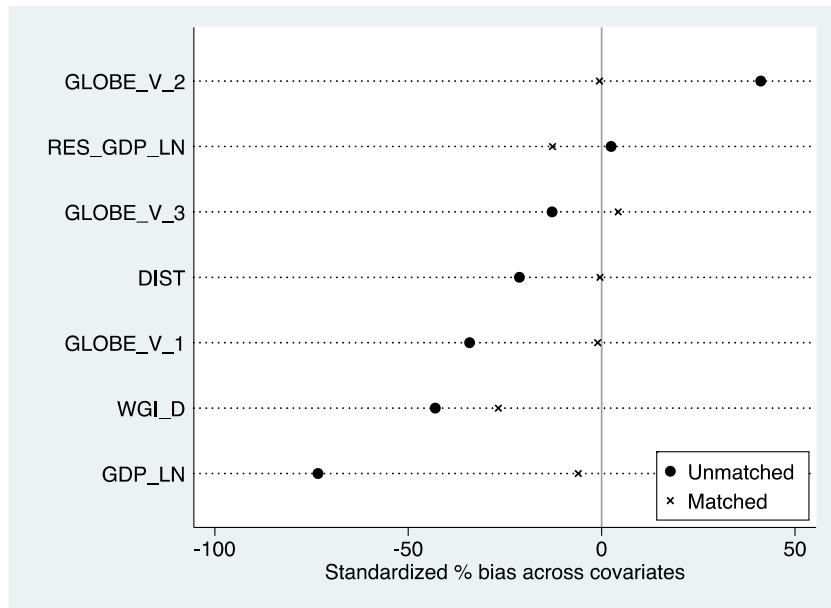

Fig. 1. The standardized bias of the covariates.

From the "Table I" below, we can see BRI Treaty's effects on China's outward FDI to the host countries. The coefficient of the Sample Average Treatment Effect (SATE) is above zero significantly with the $\mathrm{P}$ value of 0.007 . The value of the SATE coefficient means that the expected value of ODIP_C_LN in the countries with BRI treaties with China is higher than in the countries with similar characteristics but out of the Belt and Road by 0.381194 , which implies that China's outward FDI in the countries with BRI treaties is higher than in the countries with similar characteristics but without such treaties by $46.4 \%\left(\mathrm{e}^{\wedge} 0.381194-1\right)$, which similar to Kang et al. (2018)'s estimation [12].

TABLE I. TREATY'S EFFECT ON ODIP_C_LN

\begin{tabular}{|l|c|c|c|c|l|}
\hline & Coef. & Std. Err. & $\mathbf{z}$ & $\mathbf{P}>|\mathbf{z}|$ & $\begin{array}{c}\text { [95\% Conf. } \\
\text { Interval] }\end{array}$ \\
\hline SATE & 0.381194 & 0.1423107 & 2.68 & 0.007 & 0.1022702 \\
& & & & & 0.6601178 \\
\hline SATT & 0.8879857 & 0.1698776 & 5.23 & 0.000 & 0.5550317 \\
& & & & & 1.22094 \\
\hline SATC & 0.3135426 & 0.1443645 & 2.17 & 0.030 & 0.0305934 \\
& & & & & 0.5964918 \\
\hline
\end{tabular}

The coefficient of the Sample Average Treatment Effect for the Treated (SATT) is also above zero significantly with the $\mathrm{P}$ value of 0.000 . The value of the SATT coefficient means that the expected value of ODIP_C_LN in the countries with BRI treaties with China is higher than if those countries does not have such treaties by 0.8879857 , which implies that China's outward FDI in the countries with BRI treaties is higher than in the countries if no such treaties exit by $143.0 \%$ $\left(\mathrm{e}^{\wedge} .8879857-1\right)$. This explains why China's outward FDI increased so much in BRCs.

The coefficient of the Sample Average Treatment Effect for the Controls (SATC) is above zero 
significantly with the $\mathrm{P}$ value of 0.030 . The value of the SATC coefficient means that the expected value of ODIP_C_LN in the countries without BRI treaties with China may increase by 0.3135426 if BRI treaties are signed with China, which implies that China's outward FDI in the countries without BRI treaties can rise by $36.8 \%\left(\mathrm{e}^{\wedge} .3135426-1\right)$. This show that China's outward FDI into other countries with similar characteristics of the countries along the Belt and Road with BRI treaties to China can grow if BRI treaties are signed by China and the host countries, although the extent is smaller than with the countries already holding BRI treaties with China.

\section{CONCLUSION}

The Belt and Road Initiative is one of the most important policies for China to promote its international economic relations with the countries along the Belt and Road. The BRI treaties between China and the host countries fosters China's outward FDI into the BRCs. In addition, if China could expand its BRI treaties engaging countries with similar traits of the BRCs, its outward FDI may grow more.

\section{References}

[1] The National Development and Reform Commission, The Ministry of Foreign Affairs, and the Ministry of Commerce of the People's Republic of China, "Vision and Actions on Jointly Building Silk Road Economic Belt and 21st Century Maritime Silk Road”, March 28th, 2015.

[2] M. X. Chen and C. Lin, "Foreign Investment across the Belt and Road Patterns, Determinants and Effects," World Bank Policy Research Working Paper 8607, October 2018.

[3] Office of the Leading Group for Promoting the Belt and Road Initiative of China, "The Belt and Road Initiative: Progress, Contributions and Prospects.” April 22, 2019.

[4] Office of the Leading Group for Promoting the Belt and Road Initiative of China, "Building the Belt and Road: Concept, Practice and China's Contribution.” May 2017.

[5] Y. Huang, "Environmental risks and opportunities for countries along the Belt and Road: Location choice of China's investment," Journal of Cleaner Production, vol. 211, pp. 14-26, 2019.

[6] Y. Wang, "Offensive for defensive: the belt and road initiative and China's new grand strategy," The Pacific Review, vol. 29, pp. $455-463,2016$.

[7] W. Liu and M. Dunford, "Inclusive globalization: unpacking China's Belt and Road Initiative," Area Development and Policy, vol. 1, pp. 323-340, 2016.

[8] F. de Soyres, A. Mulabdic, S. Murray, N. Rocha, and M. Ruta, "How much will the Belt and Road Initiative reduce trade costs?," International Economics, vol. 159, pp. 151-164, 2019.

[9] S.-C. Chen, J. Hou, and D. Xiao, "“One Belt, One Road" Initiative to Stimulate Trade in China: A Counter-Factual Analysis," Sustainability, vol. 10, p. 3242, 2018.

[10] X.-M. Fu, H.-X. Chen, and Z.-K. Xue, "Construction of the Belt and Road Trade Cooperation Network from the Multi-Distances Perspective," Sustainability, vol. 10, p. 1439, 2018.
[11] J. Du and Y. Zhang, "Does One Belt One Road Initiative Promote Chinese Overseas Direct Investment?," China Economic Review, vol. 47, pp. 189-205, 2018.

[12] L. Kang, F. Peng, Y. Zhu, and A. Pan, "Harmony in Diversity: Can the One Belt One Road Initiative Promote China's Outward Foreign Direct Investment?," Sustainability, vol. 10, p. 3264, 2018.

[13] S. Yu, X. Qian, and T. Liu, "Belt and road initiative and Chinese firms' outward foreign direct investment," Emerging Markets Review, vol. 41, p. 100629, 2019.

[14] H. Y. Liu, Y. K. Tang, X. L. Chen, and J. Poznanska, "The Determinants of Chinese Outward FDI in Countries Along "One Belt One Road"," Emerging Markets Finance and Trade, vol. 53, pp. 1374-1387, 2017.

[15] F. Duan, Q. Ji, B.-Y. Liu, and Y. Fan, "Energy investment risk assessment for nations along China's Belt \& Road Initiative," Journal of Cleaner Production, vol. 170, pp. 535-547, 2018.

[16] J. H. Dunning, "Trade, Location of Economic Activity and the MNE: A Search for an Eclectic Approach," pp. 395-418, 1977.

[17] P. J. Buckley, L. J. Clegg, A. R. Cross, X. Liu, H. Voss, and P. Zheng, "The determinants of Chinese outward foreign direct investment," Journal of International Business Studies, vol. 38 pp. 499-518, 2007

[18] X. Zhang and K. Daly, "The determinants of China's outward foreign direct investment," Emerging Markets Review, vol. 12, pp. 389-398, 2011

[19] I. Kolstad and A. Wiig, "What determines Chinese outward FDI?," Journal of World Business, vol. 47, pp. 26-34, 2012.

[20] Y. Wang, J. Du, and K. Wang, "The Determinants of Location Choices of China's ODI," Frontiers of Economics in China, vol. 10, pp. 540-565, 2015.

[21] G. H. Hofstede, Culture's Consequences: Comparing Values, Behaviors, Institutions and Organizations Across Nations California: Sage Publications, 2001 